\title{
T. E. Freeman, 1930 to 2003
}

\author{
F. W. Zettler and G. Wisler
}

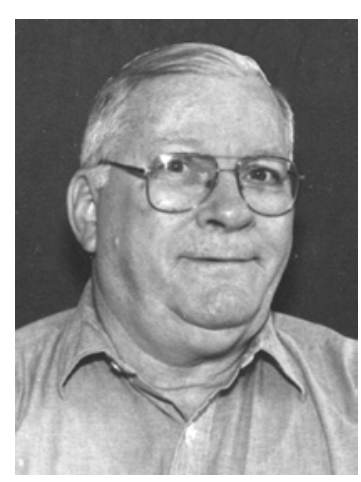

Dr. Thomas Edward (Ed) Freeman, plant pathologist and turfgrass specialist, died on Tuesday, September 16, 2003 in Gainesville, Florida, at the age of 73. Ed was a native of Mississippi, where he attended primary and secondary schools. He received his bachelor of science degree in biology from Millsap College in 1952. Ed earned his MS and Ph.D. degree in plant pathology in 1954 and 1956, respectively, from Louisiana State University, after which he joined the faculty of the University of Florida's Plant Pathology Department. He was a member of Lambda Chi Alpha fraternity, Sigma Xi, and Phi Kappa Phi. Ed served the university in the capacities of assistant, associate, and professor of plant pathology, acting department chairman, and acting assistant Dean for research. Although holding teaching and extension assignments at various times, his primary efforts have been in basic and applied research in two areas: (i) elucidation of the etiology, occurrence, and control of turfgrass diseases and (ii) biological control of weeds (primarily aquatic) with plant pathogens. From 1980 to 1992, Ed coordinated the UF/IFAS turfgrass program. In that capacity, he worked closely with the turfgrass industry through the Florida Turfgrass Association. In 1985, this group honored him with their highest award, the coveted "Wreath of Grass." In 1992, they further honored him with a special achievement award "To honor a career of distinguished service to Florida's turf industry through his contributions of research and education." After he retired, he built a cactus-growing hobby into a "beer money" enterprise. He also was an avid saltwater fisherman, spending much of his time in Cedar Key, Florida. He was a president of the Gainesville Offshore Fishing Club and an active member of the Kiwanis Club.

Dr. Freeman was a positive influence on the lives of his students. In noting those influences, former graduate students Drs. Michael T. Olexa, Director of the Agricultural Law Center at the University of Florida, and Raymond D. Martyn, Jr., Chair of the Botany and Plant Pathology Department at Purdue University, stated that he allowed them the freedom to explore many avenues of research, which helped nurture the creative spirit of good scientists and educators. Both agreed that one of the most important lessons they learned from their mentor was that you're never too old to learn. He always expected his students to do more and learn more than he did. Ed Freeman was never ashamed to admit that he didn't know something and was eager to learn about a new technique or result. Both aforementioned students have applied his philosophy of learning to their own students and career development. To these and other former students, he was a quiet man, a great man, and a good friend and mentor.

Dr. Freeman is survived by his wife of 50 years, Ruth Imogene (Gene); son, Thomas Harrell; daughter, Roxane Ethel McGinnis; brother, Barry Freeman; and grandchildren, Whitney and Mason McGinnis. 